\title{
Relationship between body collagen and urinary hydroxyproline excretion in young rats fed on a low-protein or low-calorie diet
}

\author{
By A. ANASUYA AND B. S. NARASINGA RAO \\ Nutrition Research Laboratories, Indian Council of Medical Research, \\ Jamai-Osmania, Hyderabad-7, India \\ (Received 29 April г969-Accepted 12 August 1969)
}

\begin{abstract}
I. Hydroxyproline was determined in urine, carcass, and skin of young rats fed on lowprotein and low-calorie diets.

2. Protein and calorie deprivation in young rats resulted in a marked fall in the soluble as well as insoluble collagen content of the skin.

3. The collagen content of the carcass (excluding skin) was slightly greater in the deficient rats than in the weanling rats, but very much lower than in the well-fed rats.

4. In rats subjected to protein and calorie deficiency, urinary hydroxyproline was markedly reduced. In these rats, most of the reduction in urinary hydroxyproline was observed within I week of feeding the deficient diet. Protein deficiency had affected urinary excretion of hydroxyproline more severely than calorie deficiency.

5. The reduction of urinary hydroxyproline in the deficient animals can be attributed to decreased turnover rate of their body collagen. This apparent decrease in turnover rate is explained as being due to an increase in the proportion of collagen of slow turnover in these animals.

6. Protein and calorie deficiency had also resulted in the depletion of non-collagen nitrogen of both carcass and skin.
\end{abstract}

Urinary excretion of hydroxyproline has been shown to be markedly lowered in children suffering from protein-calorie malnutrition (Picou, Alleyne \& Seakins, 1965; Whitehead, 1965 ; Anasuya \& Narasinga Rao, I966). A reduction in the urinary excretion of hydroxyproline has also been observed in normal adults fed on a low-protein $\operatorname{diet}(3 \mathrm{~g} /$ day) for as short a period as Io days (A. Anasuya \& B. S. Narasinga Rao, unpublished results).

Reduced excretion of hydroxyproline in protein-deficiency states may be due to a reduced content of body collagen, both soluble and insoluble, or to an altered metabolism of collagen. Picou et al. (1965), and Picou, Halliday \& Garrow (1966) have suggested that reduced excretion of urinary hydroxyproline in malnourished children may be due to reduced catabolism of body collagen. However, no convincing evidence is available to show that in protein malnutrition, the catabolism of collagen is actually decreased. The relationship between body collagen and urinary excretion of hydroxyproline was therefore studied in experimental protein-calorie deficiency in young albino rats.

\section{MATERIALS AND METHODS}

\section{Animals and diets}

Thirty-two male albino rats, 28 days old, were grouped in respect of litter and initial body-weights and allocated to four groups at random such that these groups were on 
average very similar. Animals in three of the groups were housed in individual metabolic cages, and were fed as follows: group I (well-fed controls) was given a $20 \%$ protein diet ad lib.; group 2 (calorie-deficient group) was given the $20 \%$ protein diet in limited amounts, so that the weight of each rat in this group was the same as that of its litter-mate in group 3 ; group 3 (low-protein group) was given a $2 \%$ protein diet ad lib.; the rats in the fourth group served as initial controls. The composition of the diets is given in Table $\mathrm{I}$; they were free from any source of hydroxyproline.

\section{Urine analysis}

The animals in groups $\mathrm{I}-3$ were kept in metabolic cages and were given initially the colony stock diet; urine was collected from three animals in each group for 3 days. The rats were then given the experimental diets for the next 30 days, and urine was

\begin{tabular}{|c|c|c|}
\hline Ingredient & $\begin{array}{l}\text { High-protein } \\
(20 \%) \text { diet }\end{array}$ & $\begin{array}{c}\text { Low-protein } \\
(2 \%) \text { diet }\end{array}$ \\
\hline Casein & 235.0 & 23.5 \\
\hline Vitamin mixture & 10.0 & $10 \%$ \\
\hline Salt mixture & $40 \cdot 0$ & $40 \cdot 0$ \\
\hline Sesame oil & $50 \cdot 0$ & $50 \cdot 0$ \\
\hline Choline chloride & $I \cdot O$ & I.O \\
\hline Maize starch & $664 \cdot 0$ & 875.0 \\
\hline
\end{tabular}

collected continuously from seven rats in each group throughout this period. Urine, which was collected in $10 \mathrm{ml}$ toluene and $0.5 \mathrm{ml} \mathrm{HCl}$ in polythene bottles, was removed daily and stored at $-4^{\circ}$ till analysed. Urine collected on 3 consecutive days was pooled and analysed for total nitrogen, creatinine and total hydroxyproline.

\section{Carcass and skin analysis}

The rats in the fourth group were killed at the beginning of the experiment, and the rest of the animals at the end of 30 days. The animals were killed in a cold room at $4^{\circ}$; the fur was shaved off and the skin, except that from the head, tail and lower part of the legs, was removed and separated carefully from fat and adhering subcutaneous tissue. The carcass (without skin), after the removal of the intestinal contents, was analysed for water, fat, total $\mathrm{N}$ and hydroxyproline. Hair-free skin was minced at $4^{\circ}$ in a meat mincer. A portion of the minced skin was used for the determination of water, fat, total hydroxyproline and total N. Another portion of the freshly minced skin was used immediately for the determination of soluble and insoluble collagen by a method similar to that described by Prockop (I964).

\section{Analytical methods}

Total $\mathrm{N}$ in urine was determined by the micro-Kjeldahl method, urinary creatinine by the method of Clark \& Thompson (1949). Water in carcass and skin was determined by drying to constant weight in an oven at $60^{\circ}$. Lipid content was determined by 
extracting dried samples of carcass and skin with chloroform-methanol mixture (2:I) for $28 \mathrm{~h}$.

Samples of urine, fat-free dry carcass and skin, and soluble and insoluble collagen of skin were hydrolysed with $6 \mathrm{~N}-\mathrm{HCl}$ at $124^{\circ}$ for $24 \mathrm{~h}$. Hydroxyproline was determined in the hydrolysed samples by the method of Prockop \& Udenfriend ( 1960 ) as modified by Jasin, Fink, Wise \& Ziff ( 1962$)$. $N$ in hydrolysates of carcass and skin was determined by the micro-Kjeldahl method.

\section{RESULTS}

\section{Growth}

The growth pattern observed in the three groups of rats is shown in Fig. 1 . The rats in group I had gained, on average, I I $5 \mathrm{~g}$, whereas the rats in groups 2 and 3 had lost about $10 \mathrm{~g}$ by the end of the experiment. The average calorie intakes per roo $\mathrm{g}$

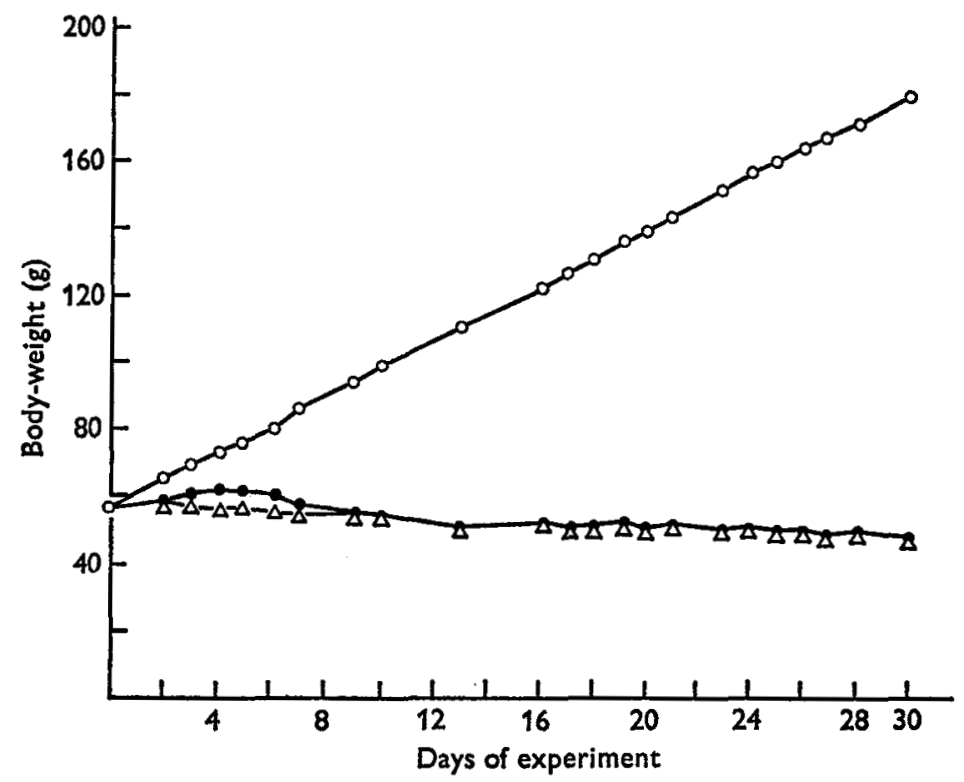

Fig. I. Growth rate of the rats during the experimental period: $\mathrm{O}-\mathrm{O}$, well-fed controls; -1 , calorie-deficient group; $\triangle-\triangle$, protein-deficient group.

body-weight per week were 298,166 and $402 \mathrm{kcal}$ in groups I, 2 and 3 respectively. The corresponding protein intakes were $15 \cdot 0,8 \cdot 4$ and $2 \cdot 0 \mathrm{~g}$ respectively. It is thus seen that while the animals in group 3 were subjected to protein restriction alone, those in the second group had suffered from deficiencies of both calories and protein. 


\section{Urinary excretion of nitrogen and hydroxyproline}

Urinary excretion of hydroxyproline and total $\mathrm{N}$ is shown in Figs. 2 and 3 respectively. The ratio of hydroxyproline to creatinine and 'hyp index' are shown in Figs. 4 and 5 respectively. 'Hyp index' was calculated as:

$$
\frac{\mu \mathrm{g} \text { hyp } / 24 \mathrm{~h}}{\mu \mathrm{g} \text { creatinine } / 24 \mathrm{~h}} \times \text { body-weight in } \mathrm{g} \text {. }
$$

Total hydroxyproline (Fig. 2). At the beginning of the experiment, the mean excretion of urinary hydroxyproline was about $230 \mu \mathrm{g} / 24 \mathrm{~h}$. In the well-fed rats (group I), urinary excretion of hydroxyproline decreased slightly during the ist week and then increased to a peak value by $2 \mathrm{I}$ days with a subsequent decrease; in contrast, that of

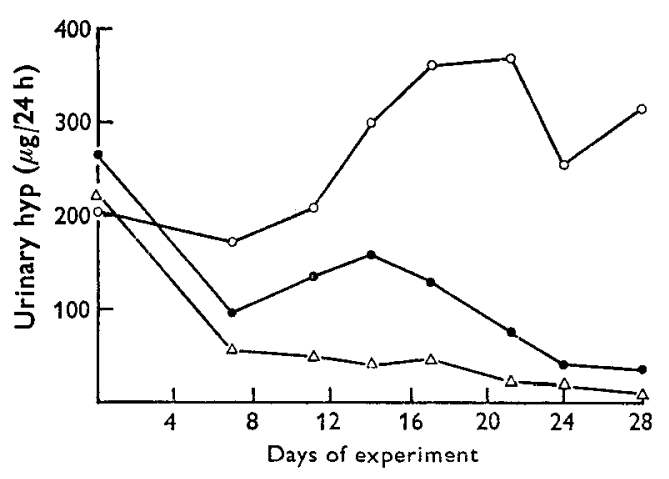

Fig. 2

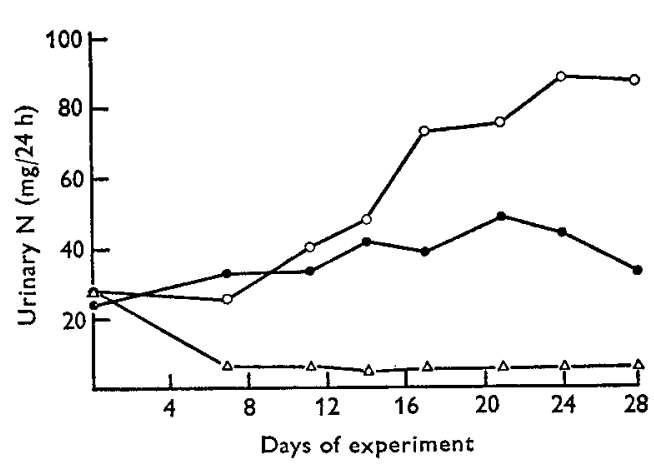

Fig. 3

Fig. 2. Pattern of urinary excretion of hydroxyproline in the experimental rats. $\mathrm{O}-\mathrm{O}$, wellfed controls; $-\rightarrow$, calorie-deficient group; $\triangle-\triangle$, protein-deficient group.

Fig. 3. Pattern of urinary nitrogen excretion in the rats during the experiment. $\mathrm{O}-\mathrm{O}$, wellfed controls; - calorie-deficient group; $\triangle-\triangle$, protein-deficient group.

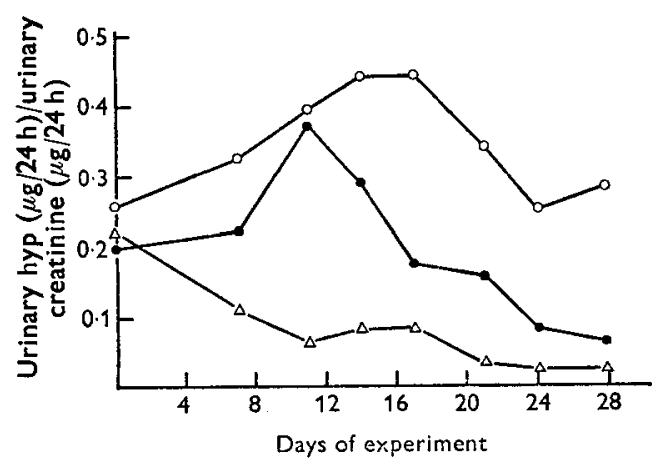

Fig. 4

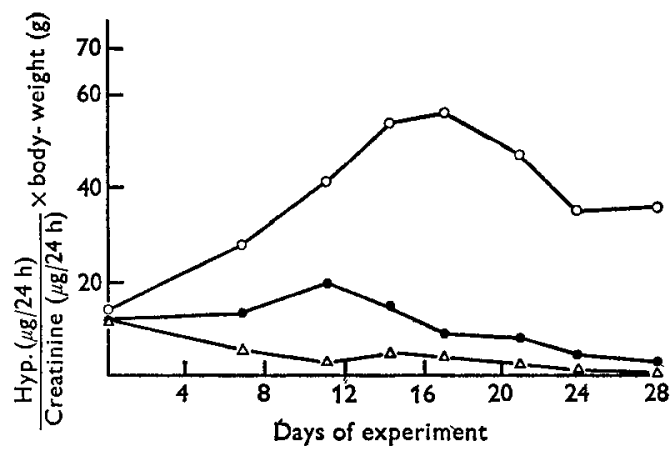

Fig. 5

Fig. 4. Pattern of urinary hydroxyproline: creatinine ratio in the rats during the experimental period. $\mathrm{O}-\mathrm{O}$, well-fed controls; $-\mathrm{O}$, calorie-deficient group; $\Delta-\Delta$, protein-deficient group.

Fig. 5. Pattern of urinary 'hydroxyproline index' during the experimental period. $\mathrm{O}-\mathrm{O}$, well-fed controls; $\longrightarrow$, calorie-deficient group; $\triangle-\triangle$, protein-deficient group. 
the rats in both the deficient groups was markedly reduced throughout the experimental period. In the protein-deficient group (group 3) a marked drop in the urinary hydroxyproline excretion occurred during the ist week and subsequently the decrease was gradual. In the calorie-deficient group (group 2), however, the excretion, though it decreased significantly during the Ist week, showed a transient increase during the 2nd week and subsequently decreased. At the end of the experiment urinary hydroxyproline excretion was significantly lower in the deficient rats than in the wellnourished rats $(P<0.00 \mathrm{I})$. This decrease was more marked $(P<0.00 \mathrm{I})$ in the rats on the low-protein diet (group 3) than in the calorie-restricted group (group 2). These differences in the urinary excretion of hydroxyproline in the three groups were apparent even when the values were expressed on the basis of body-weight or urinary creatinine excretion. A comparison of changes in urinary excretion of hydroxyproline (Fig. 2), hydroxyproline to creatinine ratio (Fig. 4) or hydroxyproline index (Fig. 5) during the experimental period indicated close similarities.

Total nitrogen (Fig. 3). At the beginning of the experiment, the rats excreted about $25 \mathrm{mg} \mathrm{N}$ in $24 \mathrm{~h}$. In the well-fed group a gradual increase in the urinary $\mathrm{N}$ excretion was observed during the experiment, and by the end of the feeding, the excretion was about $86 \mathrm{mg} \mathrm{N} /$ day. Urinary $\mathrm{N}$ excretion in the protein-deficient animals fell rapidly at first and then slowly to a low value of $3.7 \mathrm{mg}$ by 28 days; in the calorie-deficient animals it increased slowly up to $2 \mathrm{I}$ days and then tended to fall. At the beginning of the experiment the animals excreted $8 \%$ of the ingested $\mathrm{N}$; at the end of the experiment, the percentages excreted in groups 1,2 and 3 were 18,54 and 19 respectively.

\section{Urinary excretion of creatinine}

There were considerable fluctuations in the creatinine excretion during the experimental period in all the groups. In the control animals creatinine excretion increased from 856 to $1063 \mu \mathrm{g}$ per $24 \mathrm{~h}$ during the experimental period, while in the caloriedeficient rats it decreased from 1500 to $458 \mu \mathrm{g}$ per $24 \mathrm{~h}$. No clear-cut pattern in creatinine excretion by the protein-deficient rats was apparent during the experimental period, because of considerable fluctuations in the amounts during the different collection periods.

\section{Composition of carcass (excluding skin)}

The results are shown in Table 2. There were no significant differences in the water content ( $\%$ of body-weight) of carcasses in groups $2-4$, whereas in the well-fed controls the water content was significantly lower. The content of fat in the carcasses of the well-fed rats was greater than in the initial controls. In the deficient rats, however, there was a significant reduction in the fat content of the carcass, the reduction being more marked in the calorie-deficient rats. The percentage $\mathrm{N}$ in the dry defatted carcass was the same in the initial controls and in the well-fed rats, but it was significantly lower $(P<0.001)$ in the protein-deficient and calorie-deficient animals.

The total hydroxyproline content of carcass in all three experimental groups had significantly increased over the levels found in the initial controls. The increase in the deficient groups, though small compared with the increase in the well-fed group, was 
significant $(P<0.05)$. The concentration of hydroxyproline in the dry defatted carcass was higher in the deficient groups of rats $(P<0.001)$ and in the well-fed rats $(P<0.001)$ than in the initial controls. However the concentration of hydroxyproline in dry defatted carcass was not significantly different in well-fed controls and deficient groups.

When the collagen $\mathrm{N}$ content of the carcass was expressed as a percentage of total $\mathrm{N}$, the values were least in the initial controls. In the deficient rats, the values were higher than in the well-fed rats $(P<0.05)$.

\section{Table 2. Effect of protein and calorie deprivation in rats on the composition of the carcass (without skin)}

(Mean values and their standard errors)

\begin{tabular}{|c|c|c|c|c|c|c|c|c|c|}
\hline \multirow[b]{2}{*}{ Group } & \multirow[b]{2}{*}{$\begin{array}{l}\text { No. of } \\
\text { rats }\end{array}$} & \multirow{2}{*}{$\begin{array}{l}\text { Carcass } \\
\text { weight } \\
\text { (g) }\end{array}$} & \multicolumn{2}{|c|}{$\begin{array}{l}\mathrm{g} / 100 \mathrm{~g} \text { fresh } \\
\text { weight }\end{array}$} & \multicolumn{2}{|c|}{$\begin{array}{c}\mathbf{g} / \mathbf{1} 00 \mathrm{~g} \text { dry } \\
\text { defatted residue }\end{array}$} & \multicolumn{2}{|c|}{$\begin{array}{c}\text { Total content of } \\
\text { the carcass }\end{array}$} & \multirow[b]{2}{*}{$\begin{array}{l}\text { Collagen } \\
\mathrm{N} \text { as } \% \text { of } \\
\text { total } \mathrm{N}\end{array}$} \\
\hline & & & Water & Fat & $N$ & Hyp & $N(g)$ & $\begin{array}{l}\text { Hyp } \\
\text { (mg) }\end{array}$ & \\
\hline $\begin{array}{l}\text { Initial controls, } \\
28 \text { days old }\end{array}$ & 6 & $\begin{array}{c}58 \cdot 3 \pm \\
I \cdot 93\end{array}$ & $\begin{array}{c}70 \cdot 7 \pm \\
1.07\end{array}$ & $\begin{array}{c}10.1 \pm \\
0.28\end{array}$ & $\begin{array}{l}\text { II.I } \pm \\
0.35\end{array}$ & $\begin{array}{l}I \cdot 52 \pm \\
0.042\end{array}$ & $\begin{array}{l}1 \cdot 30 \pm \\
0.05\end{array}$ & $\begin{array}{c}173 \cdot 6 \pm \\
5.73\end{array}$ & $\begin{array}{c}18 \cdot 1 \pm \\
1 \cdot 24\end{array}$ \\
\hline $\begin{array}{l}\text { Well-fed } \\
\text { controls }\end{array}$ & 8 & $\begin{array}{c}I 50.9 \pm \\
I .96\end{array}$ & $\begin{array}{c}63.0 \pm \\
0.30\end{array}$ & $\begin{array}{c}\text { I } 5.9 \pm \\
0.33\end{array}$ & $\begin{array}{l}11 \cdot 3 \pm \\
0.14\end{array}$ & $\begin{array}{l}x \cdot 87 \pm \\
0.027\end{array}$ & $\begin{array}{l}3.8 \pm \\
0.05\end{array}$ & $\begin{array}{c}631 \cdot 8 \pm \\
15 \cdot 87\end{array}$ & $\begin{array}{c}22 \cdot 6 \pm \\
0 \cdot 13\end{array}$ \\
\hline Calorie-deficient & 8 & $\begin{array}{c}42 \cdot 6 \pm \\
2 \cdot 52\end{array}$ & $\begin{array}{c}71 \cdot 4 \pm \\
0.66\end{array}$ & $\begin{array}{l}4.1 \pm \\
0.26\end{array}$ & $\begin{array}{l}9.9 \pm \\
0.24\end{array}$ & $\begin{array}{l}2.04 \pm \\
0.103\end{array}$ & $\begin{array}{l}1.02 \pm \\
0.06\end{array}$ & $\begin{array}{c}211 \cdot 2 \pm \\
5 \cdot 40\end{array}$ & $\begin{array}{r}28 \cdot 3 \pm \\
r \cdot 46\end{array}$ \\
\hline Protein-deficient & 8 & $\begin{array}{c}4 I \cdot 7 \pm \\
2 \cdot 11\end{array}$ & $\begin{array}{c}68 \cdot 4 \pm \\
I \cdot 17\end{array}$ & $\begin{array}{l}7 \cdot 2 \pm \\
0.51\end{array}$ & $\begin{array}{l}9.9 \pm \\
0.09\end{array}$ & $\begin{array}{l}2.01 \pm \\
0.036\end{array}$ & $\begin{array}{l}0.96 \pm \\
0.06\end{array}$ & $\begin{array}{c}201 \cdot 9 \pm \\
9 \cdot 54\end{array}$ & $\begin{array}{c}27 \cdot 8 \pm \\
0.92\end{array}$ \\
\hline
\end{tabular}

\section{Hydroxyproline and nitrogen content of skin}

The results are given in Table 3 . While, in the well-fed control animals, the weight of the skin had more than doubled at the end of the experiment, as compared to that of the initial controls, in the animals of both the deficient groups, it had been reduced to $30 \%$ of the weight of skin of the weanling rats. The water content of skin was lower in the well-fed controls and deficient animals as compared to the initial controls. This lowering was more marked in the well-fed controls than in the deficient animals. These changes in the water content of skin were statistically significant $(P<0.05)$.

As compared to the weanling rats, the percentage fat content of the skin of the well-fed rats had increased significantly $(P<0.00 \mathrm{I})$, while that of the deficient rats had decreased. The decrease was much greater in the calorie-restricted group than in the protein-deficient group $(P<0 \cdot 001)$.

The percentage of total $\mathrm{N}$ in the fat-free dry skin was similar in the weanling rats and in the well-fed rats. On the other hand, the percentage of $\mathrm{N}$ in the fat-free dry skin of the deficient animals was significantly lower $(P<0 \cdot 05)$. During the experimental period, the total $\mathrm{N}$ content of skin had increased in the well-fed animals while it had decreased $(P<0.001)$ in the deficient animals.

The hydroxyproline concentration in the neutral salt-soluble fraction of the skin was highest in the weanling rats and had decreased $(P<0.00 \mathrm{I})$ in the older well-fed rats. In the depleted rats, however, the value was significantly lower $(P<0.00$ I $)$ than 
Vol. 24

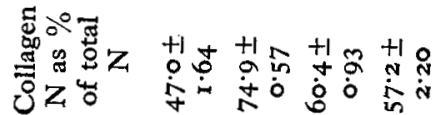

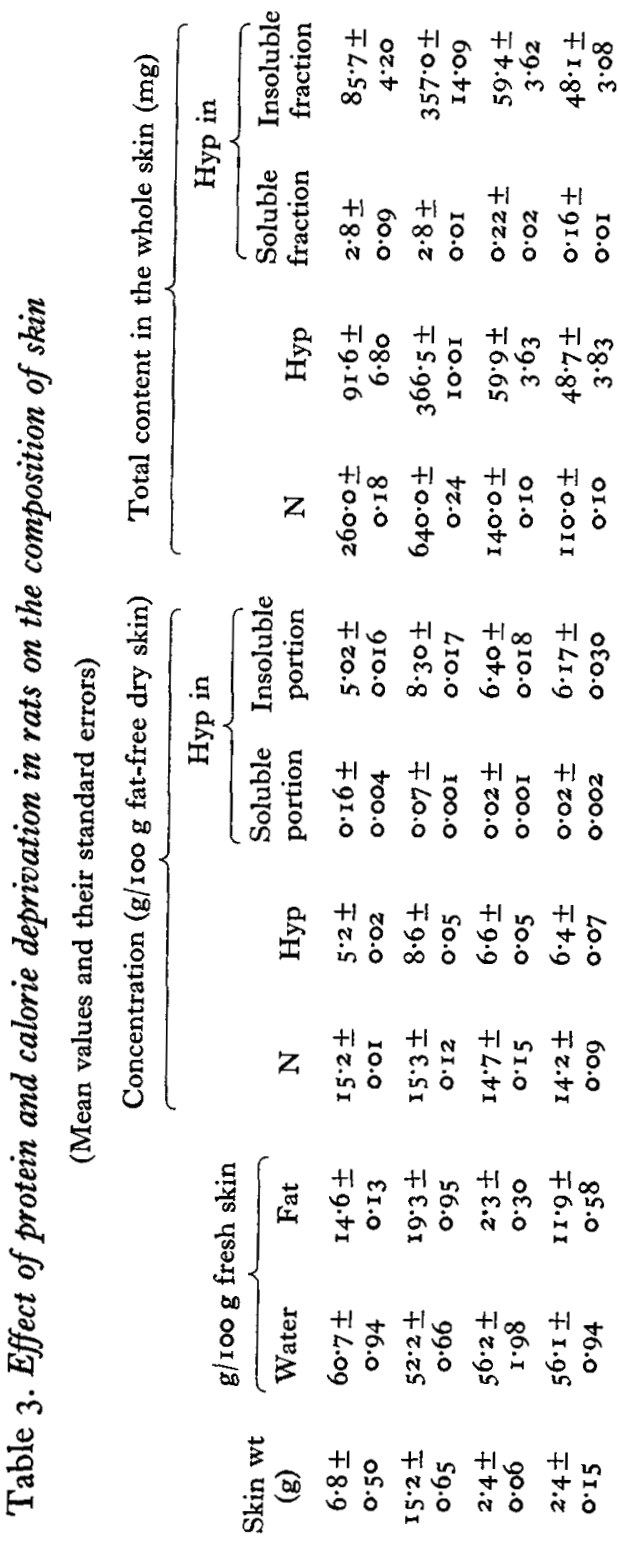

它岁颉 $0 \quad \infty \quad \infty \quad \infty$

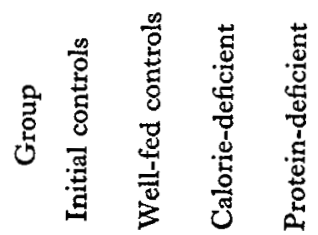


in the well-fed rats. This reduction was greater in the protein-deficient rats than in the calorie-restricted group $(P<0.001)$. The hydroxyproline concentration in the soluble portion calculated for the total skin was almost the same in both the initial controls and the well-fed controls, but in the deficient groups the value was markedly reduced $(P<0.001)$.

The concentration of skin hydroxyproline not extractable with $0 \cdot \mathrm{I} \mathrm{M}-\mathrm{NaCl}$ was higher in the older rats than in the weanling rats. However, in the protein- or caloriedeficient rats, the increase was very much less than in the well-fed animals $(P<0.001)$. The ratio of soluble to insoluble hydroxyproline of skin was highest in the weanling rats and lowest in the deficient animals. This ratio decreased with age and much more so during protein or calorie depletion.

Total collagen concentration, and the ratio of collagen $N$ to total $N$ in skin was lowest in the weanling rats, and these values increased with age. The increase was more in the well-fed rats, than in the deficient rats $(P<0.05)$.

\section{DISCUSSION}

It was observed in the present study that, in animals that were growing fast, there was a gradual increase in urinary excretion of hydroxyproline, whereas in animals whose growth was arrested owing to protein or calorie restriction there was a marked decrease. The pattern of hydroxyproline excretion during the period of protein or calorie depletion was similar when expressed either as total daily excretion or as the hydroxyproline to creatinine ratio or as 'hyp index'. In general the pattern of total urinary hydroxyproline excretion by the different groups of rats observed in this study was similar to that reported by Widdowson \& Whitehead (1966). As regards the hydroxyproline to creatinine ratio and 'hyp index' also, the changes observed in these two studies were similar except for the initial fall during the ist week of feeding of the experimental diets. In the study reported by Widdowson \& Whitehead (I966) this decrease was more marked in the deficient groups, but the decrease was observed even in the well-nourished group, unlike in the present study. In the study of Widdowson \& Whitehead (1966) creatinine excretion appeared to almost double by the end of the Ist week in all the groups, resulting in a marked decrease in the hydroxyproline to creatinine ratio and 'hyp index'.

These observations on hydroxyproline excretion in protein-depleted rats confirm the finding in protein-malnourished children in whom hydroxyproline excretion has been found to be markedly reduced (Picou et al. 1965; Whitehead, 1965; Anasuya \& Narasinga Rao, 1966). In clinical cases of protein malnutrition, observation on urinary excretion of hydroxyproline is normally made at a point where protein deficiency is fairly well established. It is not clear from such studies at what stage in the development of protein deficiency hydroxyproline excretion decreases markedly. It is evident from the present study with experimental animals, that a sharp fall in the urinary excretion of hydroxyproline occurs at an early stage (within I week) of protein and calorie deficiencies and thereafter the decrease is slow. This would mean that most of the effect of protein deficiency on the urinary hydroxyproline would be evident 
during the early phase of development of protein deficiency. The results of the experiment with normal adult men showed that even a short period of feeding a protein-free diet can result in a substantial decrease in the urinary hydroxyproline excretion (A. Anasuya \& B. S. Narasinga Rao, unpublished finding). In the present experiments, though the excretion of hydroxyproline was markedly reduced in the proteindeficient animals, the excretion of creatinine was not affected to the same degree, so that the hydroxyproline to creatinine ratio was lower in depleted animals than in well-fed animals. This is in contrast to the situation observed in kwashiorkor where this ratio was not different from that found in normal children (Anasuya \& Narasinga

\section{Table 4. Relation between total body hydroxyproline and urinary hydroxyproline in well-fed and in protein-deficient and calorie-deficient rats}

\begin{tabular}{|c|c|c|c|c|c|c|}
\hline \multicolumn{7}{|c|}{ (Mean values and their standard errors) } \\
\hline & \multicolumn{4}{|c|}{ Total body composition } & \multirow{2}{*}{$\begin{array}{l}\text { Total urinary } \\
\text { hyp excretion } \\
\text { on day of } \\
\text { killing } \\
(\mu \mathrm{g} / 24 \mathrm{~h})\end{array}$} & \multirow{2}{*}{$\begin{array}{c}\text { Urinary hyp } \\
\text { as } \% \text { of } \\
\text { body hyp }\end{array}$} \\
\hline Group & $\begin{array}{l}\text { No. of } \\
\text { rats }\end{array}$ & $\begin{array}{l}\text { Dry defatted } \\
\text { residue }(\mathrm{g})\end{array}$ & $N(g)$ & Hyp (mg) & & \\
\hline Initial controls & 6 & $\begin{array}{c}13 \cdot 2 \pm \\
0.31\end{array}$ & $\begin{array}{l}I \cdot 5 \pm \\
0.03\end{array}$ & $\begin{array}{c}265 \cdot 4 \pm \\
5.67\end{array}$ & $\begin{array}{c}248.8 \pm \\
9.02\end{array}$ & $\begin{array}{l}0.95 \pm \\
0.03\end{array}$ \\
\hline Well-fed controls & 7 & $\begin{array}{c}37 \cdot 4 \pm \\
0.31\end{array}$ & $\begin{array}{l}4.4 \pm \\
0.07\end{array}$ & $\begin{array}{c}998 \cdot 4 \pm \\
17 \cdot 44\end{array}$ & $\begin{array}{c}327 \cdot 2 \pm \\
16 \cdot 74\end{array}$ & $\begin{array}{l}0.33 \pm \\
0.02\end{array}$ \\
\hline Calorie-deficient & 7 & $\begin{array}{c}11 \cdot 4 \pm \\
0.69\end{array}$ & $\begin{array}{l}x \cdot 1 \pm \\
0.07\end{array}$ & $\begin{array}{c}271 \cdot 3 \pm \\
7 \cdot 90\end{array}$ & $\begin{array}{c}33.9 \pm \\
6.90\end{array}$ & $\begin{array}{l}0.13 \pm \\
0.02\end{array}$ \\
\hline Protein-deficient & 7 & $\begin{array}{c}10.7 \pm \\
0.52\end{array}$ & $\begin{array}{l}1.0 \pm \\
0.05\end{array}$ & $\begin{array}{c}250 \cdot 1 \pm \\
12 \cdot 25\end{array}$ & $\begin{array}{c}10 \cdot 7 \pm \\
1.77\end{array}$ & $\begin{array}{l}0.04 \pm \\
0.01\end{array}$ \\
\hline
\end{tabular}

Rao, I966). This would suggest that in a prolonged protein deficiency, as in clinical cases of protein malnutrition, creatinine excretion is also reduced to the same degree as that of hydroxyproline, resulting in an unaltered ratio of hydroxyproline to creatinine.

The reduction observed in urinary hydroxyproline excretion both in clinical cases of protein malnutrition and in protein-depleted experimental animals, can be expected to result from: $(a)$ reduced body collagen content, $(b)$ reduced synthesis, or $(c)$ reduced catabolism of collagen, or both $(b)$ and $(c)$. Picou et al. (1965, 1966) suggested, from indirect evidence obtained on the body collagen content of malnourished children, that reduced catabolism of collagen in protein undernutrition may be responsible for the lowered excretion of hydroxyproline.

It is possible from the present study to correlate changes in urinary hydroxyproline excretion with changes in body collagen in conditions of protein and calorie deficiencies and to draw some conclusions regarding alterations in collagen metabolism which lead to reduced urinary excretion of hydroxyproline. It was observed that in protein- and calorie-depleted rats skin collagen was markedly reduced while carcass collagen was hardly affected. In the skin, the reduction of collagen $N$ was greater than that of non-collagen $N$ whereas, in the carcass, non-collagen $N$ was affected more. These findings are in line with the earlier observations of Cabak, Dickerson \& Widdowson 
(1963) who observed a marked loss in skin collagen in protein- and calorie-deficient rats. Waterlow \& Stephen ( 1966 ) have also observed that in animals on a low-protein diet skin contributes a larger proportion of body $\mathrm{N}$ deficit than other tissues. A marked loss in skin collagen in clinical cases of protein malnutrition has also been reported (Halliday, 1967; Vasantha, 1970). The relationship between urinary hydroxyproline, body collagen and body $\mathrm{N}$ in different groups is shown in Table 4. As compared to the initial controls, though total body $\mathrm{N}$ had decreased in deficient animals, total body hydroxyproline had not changed. Urinary hydroxyproline excretion as a percentage of body hydroxyproline content was $1 \%$ in the initial controls (i.e. 28 -dayold rats) and $0.33 \%$ in well-fed controls (after 30 days of experiment), while in protein- and calorie-depleted rats these values were $0.04 \%$ and $0.13 \%$ respectively. This would indicate that young rats excrete relatively more hydroxyproline in relation to body collagen than older animals, a fact which supports the view that collagen turnover decreases with age. Further, the deficient animals excreted less hydroxyproline in relation to body collagen, not only when compared to the well-fed animals of the same age, but also when compared to the younger initial controls, indicating a marked decrease in the turnover of body collagen.

It is well known that the body contains different collagen pools with different turnover rates (Lindstedt \& Prockop, 1961; Laitinen, 1967). Even in a given tissue soluble collagen has a higher turnover rate than insoluble collagen. It is recognized that young and growing animals have in their body a higher proportion of soluble collagen and excrete relatively greater amounts of hydroxyproline in urine compared to older animals. Isotopic experiments carried out by Prockop (1964) suggested that urinary hydroxyproline may be derived from both soluble and insoluble collagen. It is suggested (Ziff, Kibrick, Dresner \& Cribetz, I956) that a greater proportion of urinary hydroxyproline in growing animals and children is derived from the soluble collagen pool with a higher turnover rate. A comparison of soluble collagen content of skin and urinary hydroxyproline excretion in weanling rats and 56-day-old control rats supports this contention. The latter had relatively less soluble collagen in skin and excreted less hydroxyproline in urine relative to body collagen. In the protein- and calorie-deficient animals insoluble collagen in skin was lost during the experiment. On the other hand, carcass (without skin) collagen content had actually increased in both the well-fed and deficient animals as compared to the weanling rats. It would appear from these results that, during protein and calorie depletion, the body loses much of its soluble collagen and tissue collagen (namely skin) with high turnover rates and is left with collagen pools with low turnover rates. This would result in urinary excretion of low levels of hydroxyproline in relation to body collagen. It is possible therefore that in conditions of protein and calorie malnutrition collagen compartments with faster turnover rates are preferentially depleted from certain organs, and hence contribute to a markedly decreased excretion of hydroxyproline. A small increase in carcass (excluding skin) collagen over its initial value in depleted animals can be explained as follows. In protein and calorie deficiency states, though other compartments of the body may be depleted, the skeletal growth continues, though at a very much reduced rate (McCance, I960). 
A comparison of the results for body collagen and urinary hydroxyproline excretion in groups 2 and 3 indicates that the effects of calorie restriction are less severe on collagen metabolism and urinary hydroxyproline excretion than those of protein depletion. As compared to the controls, group 2 had a lower intake of calories as well as of protein per $100 \mathrm{~g}$ body-weight, while group 3 received adequate calories but much less protein. Group 2 received more protein than group 3. In animals whose growth was stunted by calorie restriction, the level of urinary hydroxyproline as well as $\mathrm{N}$ was higher than in animals given diets adequate in calories but low in protein. These differences may operate in human subjects also. Whitehead ( 1965 ) has reported that hydroxyproline excretion is not so severely reduced in marasmus as in kwashiorkor. Calorie-restricted animals may be catabolizing body collagen at a higher rate than protein-depleted animals, thus accounting for a higher level of urinary hydroxyproline. This is evident from the findings presented in Table 4. Urinary excretion of hydroxyproline as a percentage of body hydroxyproline content was higher in the calorie-deficient animals than in the protein-depleted animals. This increased catabolism is reflected in the excretion of a higher level of urinary $\mathrm{N}$ also. Since the total body collagen in the calorie-deficient animals was not different from that of protein-depleted animals, the synthesis of collagen also should be higher in the calorie-deficient animals than in the protein-depleted animals.

The authors would like to express their thanks to Dr C. Gopalan, Director, Nutrition Research Laboratories, for his interest and encouragement during this study.

\section{REFERENCES}

Anasuya, A. \& Narasinga Rao, B. S. (1966). Indian Y. med. Res. 54, 849.

Cabak, V., Dickerson, J. W. T. \& Widdowson, E. M. (1963). Br. F. Nutr. I7, 601.

Clark, L. C. Jr \& Thompson, H. L. (1949). Analyt. Chem. 21, 1218.

Halliday, D. (I967). Clin. Sci. 33, 365 .

Jasin, H. E., Fink, C. W., Wise, W. \& Ziff, M. (I962). F. clin. Invest. 41, I 928.

Laitinen, O. (1967). Acta endocr. Copenh. Suppl. no. 120, p. 24.

Lindstedt, S. \& Prockop, D. J. (I96I). F. biol. Chem. 236, 1399.

McCance, R. A. (1960). Br. F. Nutr. 14, 59.

Picou, D., Alleyne, G. A. O. \& Seakins, A. (1965). Clin. Sci. 29, 517.

Picou, D., Halliday, D. \& Garrow, J. S. (1966). Clin. Sci. 30, 345.

Prockop, D. J. (1964). F. clin. Invest. 43, 453.

Prockop, D. J. \& Udenfriend, S. (1960). Analyt. Biochem. 1, 228.

Vasantha, L. (1970). Am. F. clin. Nutr. (In the Press.)

Waterlow, J. C. \& Stephen, J. M. I. (I966). Br. F. Nutr. 20, 46 I.

Whitehead, R. G. (1965). Lancet ii, 567 .

Widdowson, E. M. \& Whitehead, R. G. (1966). Nature, Lond. 212, 683.

Ziff, M., Kibrick, A., Dresner, E. \& Gribetz, H. J. (1956). Y. clin. Invest. 35, 579. 